\title{
GASTROESOPHAGEAL REFLUX IN NEWBORNS AND INFANTS (I)
}

\author{
Valeriu V. Lupu, Ancuta Ignat, Gabriela Paduraru, Marin Burlea \\ Pediatrics Department, "Gr. T. Popa" University of Medicine and Pharmacy, Iasi
}

\begin{abstract}
Gastroesophageal reflux in newborns and infants is particularized by pathogeny, diagnosis and therapeutical approach. The situation is much more complex for them due to the functional immaturity of the digestive tract, to the anatomic immaturity of the Hiss lower esophageal sphincter and to the lower gastric acidity. In infants, the low compliance with the laborious procedures such as $\mathrm{pH}$-metry, impedance - pH-metry and digestive endoscopy is also considered. The border between regurgitations, physiological gastroesophageal reflux and the reflux disease is sometimes hard to establish. Changing the life style of infants (feeding and position changes) based on the mother's compliance with the medical recommendations is a first step in the treatment of GER, followed in non-responsive cases by pharmacological therapy and surgery.
\end{abstract}

Keywords: gastroesophageal reflux, newborn, infant

\section{INTRODUCTION}

Gastroesophageal reflux (GER) is the intermittent or permanent passage of the gastric content into the esophagus. It is one of the most frequent gastrointestinal problems in infants and it affects approximately $50 \%$ of the healthy full term babies (1). Postprandial regurgitation is the most frequent sign of GER in infants. It is physiological in the first 3 months of life. Regurgitations usually disappear by 12 to 24 months. Risk categories are represented by: premature and dysmature infants, newborns who suffered from hypoxia or perinatal asphyxia, infants who benefitted from an "a demeure" gastric probe, infants with "gastric emptying retardation", newborns operated for esophageal atresia, encephalopathic patients (2).

\section{EPIDEMIOLOGY}

The prevalence of the pathologic GER is not accurately established in the small child. According to parents' statements, between 5 and $50 \%$ of the infants under 1 year old have frequent regurgitation episodes raising the suspicion of pathologic GER
$(3,4)$. The authors of a study reported the presence of repeated regurgitations in approximately $5 \%$ of the infants between 2 and 4 months (5). Unfortunately, the prevalence of reflux in infants and small children is influenced by the fact that the original diagnosis is for the most part based on the parents' accounts. Parents are not always aware of the symptoms and can overlook GER signs. The frequency and severity of the reflux depends on numerous factors such as the infant's sleeping position, activity (crying), feeding manner, food type and medication $(6,7)$.

The incidence of regurgitations is similar in breastfed infants and formula-fed infants (8).

\section{ETHIOPATHOGENESIS}

Three pathogenic mechanisms allowing the gastric content to reflow into the esophagus have been identified: lower esophageal sphincter dysfunction, esophageal dysfunction and gastric dysfunction.

The lower esophageal sphincter (LES) dysfunction is caused by mechanic dysfunctions (shortening of the intraabdominal segment of the esophagus), LES dystonia (changes in anatomic relations,

Corresponding author:

Ancuta Ignat, "Gr. T. Popa" University of Medicine and Pharmacy, 16 Universitatii Street, Iasi

E-mail: anca_ign@yahoo.com 
conditions of the sphincteral and esophageal muscles in systemic diseases - scleroderma, Sjögren syndrome, diabetes mellitus, myxedema, systemic erythematous lupus, polymyositis), food (chocolate, pepper, fats, carbonated drinks, citrus fruits, tomatoes). Moreover, the lower esophageal resting pressure can be changed by medication; reduced by anticholinergics, theophylline, caffeine, nicotine, alcohol, dopaminergic drugs, epinephrine, E1 and E2 prostaglandins, certain hormones (glucagon, secretin, cholecystokinin, progesterone, estrogen); increased by: cholinergic drugs, dopamine receptor antagonists, serotonin, histamine, norepinephrine, phenylephrine, gastrin.

Poor esophageal clearance is caused by esophageal dysfunction. 4 mechanisms are responsible for its efficiency: the motor activity of the esophagus (peristaltic waves), motility disturbance causes GER; the gravitational force - if absent, the clearance is delayed; the saliva secretion - due to its bicarbonate content it buffers the acid re-flown from the stomach, the decrease in saliva secretion being caused by: tobacco, anticholinergic medication, radiotherapy, xerostomia; the secretion of the esophageal (mucous and non-mucous) glands.

Gastric dysfunction is caused by: increase in the gastric volume (overfeeding), gastric distension (aerophagia, prolonged overfeeding), increase in the intraabdominal pressure (obesity, coughing effort, sneeze, defecation), delayed gastric emptying (abnormal antral motility), duodenal-gastric reflux, gastric hypersecretion (causes perturbations of the normal esophageal peristalsis).

\section{CLINICAL MANIFESTATIONS}

Non-complicated GER involves a functional or physiological process in a healthy child, without subjacent systemic anomalies. Healthy infants can have high prevalence of reflux symptoms, such as daily regurgitations $(40 \%)$, mild respiratory symptoms, crying for more than one hour a day (17\%), arching (10\%), or daily hiccups (36\%) (9). The GER that is complicated by excessive crying, irritability, sleep perturbations, lack of appetite, stationary weight curve or respiratory complications can usually be clinically diagnosed without an extended evaluation. In $85 \%$ of the infants with non-complicated GER, it is self-limited, and it usually disappears between the age of 6 and 12 months (10).

The gastroesophageal reflux disease (GERD) is a pathologic process in infants manifested through difficult weight gain, esophagitis, hidden hemorrhages, anemia, persistent respiratory symptoms or complications and neurobehavioural changes. GERD appears in approximately 1 out of 300 infants (11). A child with GERD has more than five reflux episodes a day, regurgitates more than $28 \mathrm{~g} /$ episode, refuses feeding, has apnea episodes, has a stationary weight curve and irritability (12).

The differentiation between GER and GERD in infants is based on clinical manifestations (Table 1).

TABLE 1. The difference between GER and GERD (13)

\begin{tabular}{|l|l|}
\hline GER & GERD \\
\hline $\begin{array}{l}\text { Regurgitations with } \\
\text { normal weight curve }\end{array}$ & $\begin{array}{l}\text { Regurgitations with weight loss or } \\
\text { stationary weight curve }\end{array}$ \\
\hline $\begin{array}{l}\text { No signs or symptoms } \\
\text { of esophagitis }\end{array}$ & $\begin{array}{l}\text { Persistent irritability, dysphagia, } \\
\text { food refusal; hematemesis, melena, } \\
\text { hyposideremia, anemia }\end{array}$ \\
\hline $\begin{array}{l}\text { No significant } \\
\text { respiratory symptoms }\end{array}$ & $\begin{array}{l}\text { Apnea and cyanosis, sleep disorders, } \\
\text { wheezing or stridor, aspiration or } \\
\text { recurrent pneumonia, chronic cough, } \\
\text { dysphonia }\end{array}$ \\
\hline $\begin{array}{l}\text { No neurobehavioural } \\
\text { symptoms }\end{array}$ & Abnormal posture (Sandifer syndrome) \\
\hline
\end{tabular}

The mechanisms for the symptomatology are represented by the stimulation of chemoreceptors and mechanoreceptors determined by the acid refluxate, which determines pyrosis and dysphagia. Respiratory manifestations are the consequence of irritation or injury of the tissues non-adapted to the presence of the refluxate. The mechanisms for the emergence of reflux esophagitis lesions are triggered by the direct action of the acid refluxate on the mucous membrane and the decrease in its resistance; in the case of an association of the duodenalgastric reflux (mixed), bile acids concur as well; the defense capacity decreases due to the decrease in quantity and quality of the mucous layer through which the $\mathrm{H}+$ ions penetrate, leading to lesions of the squamous epithelium by destructing intracellular junctions.

The symptoms or complications of reflux in infants include: food refusal, stationary weight curve, irritability, sleep disorders and respiratory symptoms. Furthermore, GERD in infants can be associated with cough, suffocation, wheezing or symptoms of the upper respiratory tract. Despite this, the GERD diagnosis based on symptoms can be difficult, especially because medication does not always improve the symptoms.

\section{Digestive manifestations}

Physiological regurgitations appear in the first weeks of life and disappear towards the age of 12 to 18 months. The pathologic ones are abnormal in duration and in number per 24 hours, are favored 
by posture changes or by the situations that increase intraabdominal pressure. In infants allergic to the cow milk protein, regurgitations and vomits cannot be differentiated from the ones specific to physiological GER $(14,15)$. In such infants, the presence of vomits decreases significantly (usually in approximately 2 weeks) after the elimination of cow milk from their diet, and reintroducing it causes the reappearance of the symptoms (16).

Vomits are accentuated by crying or the reclining position.

Rumination (merycism) is repetitive regurgitation of food from the stomach, followed by its chewing and re-swallowing or expulsion from the mouth. Its debut is between months 3 and 6 of life. Rumination in infants is a rare but serious condition, which can develop when there is no mutual interaction between the child and his caregiver. The child learns to bring the gastric content back into his mouth as a self-stimulation means and in order to satisfy his needs that are not satisfied by his caregiver (17).

The differential diagnosis with other pathologies associated to vomits or regurgitations is necessary (Table 2) (18).

Dysphagia is rare, as it is the expression of esophagitis lesions. This is suspected in the infant or child who refuses the bottle or the teaspoon.
Dysphagia emerges in association with oral or esophageal anatomic anomalies, neurological and motor disorders, oral or esophageal inflammatory diseases. GERD is quoted as a reason of dysphagia or odynophagia, but there are no studies on children to demonstrate this relation, as the symptomatology did not improve after the anti-reflux therapy.

Digestive hemorrhages are manifested by small hematemesis.

Sialorrhea is triggered by the esophageal-salivary reflex when the re-flown gastric content comes into contact with the esophageal mucous membrane.

\section{Respiratory manifestations}

Respiratory manifestations are expressed by chronic cough, obstructive apnea crises, wheezing, chronic or recurrent pneumonia, cyanosis attacks accompanied by stridor, hiccup, dysphonia, aspiration pneumonias, recurring obstructive bronchitis or recurring otitis media.

The association with GERD of the respiratory manifestations has been explained in time through 3 theories: micro aspiration of acid refluxate into the respiratory tract, suggested by the anatomic relation between the digestive and the respiratory tracts; the common embryonic origin of the esophageal and pulmonary nervous fibers - vagal medi-

TABLE 2. Alarming symptoms suggesting diseases other than GER (18)

\begin{tabular}{|c|c|c|}
\hline Signs and symptoms & Possible diagnosis implications & Recommended actions \\
\hline \multicolumn{3}{|l|}{ Gastrointestinal diseases } \\
\hline $\begin{array}{l}\text { Frequent strong vomits } \\
\text { (in the form of a projectile) }\end{array}$ & $\begin{array}{l}\text { They may suggest hypertrophic pyloric stenosis in } \\
\text { infants up to } 2 \text { months old }\end{array}$ & Surgical intervention \\
\hline Bile vomits & They may suggest intestinal obstruction & Surgical intervention \\
\hline $\begin{array}{l}\text { Hematemesis except for the blood swallowed } \\
\text { (epistaxis, nipple cracks in the case of } \\
\text { breastfed infants) }\end{array}$ & $\begin{array}{l}\text { It may suggest esophagus, stomach or upper intestine } \\
\text { hemorrhage }\end{array}$ & Specialty examination \\
\hline $\begin{array}{l}\text { The debut of regurgitations and/or vomits } \\
\text { after } 6 \text { months or persisting after } 1 \text { year }\end{array}$ & $\begin{array}{l}\text { The late debut suggests another cause than reflux } \\
\text { (for instance, urinary tract infection) }\end{array}$ & $\begin{array}{l}\text { Specialty examination } \\
\text { Microbiological urine test }\end{array}$ \\
\hline Blood in stool & $\begin{array}{l}\text { It may suggest a variety of conditions such as bacterial } \\
\text { gastroenteritis, cow milk protein allergy (CMPA), or an } \\
\text { acute surgical condition }\end{array}$ & $\begin{array}{l}\text { Specialty examination } \\
\text { Microbiological stool test }\end{array}$ \\
\hline $\begin{array}{l}\text { Abdominal distension, sensitivity or palpable } \\
\text { mass }\end{array}$ & $\begin{array}{l}\text { It may suggest intestinal obstruction or another acute } \\
\text { surgical condition }\end{array}$ & Surgical intervention \\
\hline Chronic diarrhea & It may suggest CMPA & Specialty examination \\
\hline \multicolumn{3}{|l|}{ Systemic diseases } \\
\hline $\begin{array}{l}\text { Influenced general state } \\
\text { Fever }\end{array}$ & Various infections & $\begin{array}{l}\text { Specialty examination } \\
\text { Clinical evaluation } \\
\text { Microbiological urine test } \\
\end{array}$ \\
\hline Bulging of the fontanelle & It may suggest high intracranial pressure (meningitis) & Specialty examination \\
\hline $\begin{array}{l}\text { The quick increase in the cranial } \\
\text { circumference (more than } 1 \mathrm{~cm} \text { a week) } \\
\text { Aggravation of morning vomits }\end{array}$ & $\begin{array}{l}\text { It may suggest high intracranial pressure } \\
\text { (hydrocephaly or brain tumor) }\end{array}$ & Specialty examination \\
\hline Altered receptivity (lethargy or irritability) & It may suggest meningitis & Specialty examination \\
\hline Infants and children with a high risk of atopy & It may suggest CMPA & Specialty examination \\
\hline
\end{tabular}


ated bronchospasm; the pulmonary manifestations can be the cause of reflux - inverse relation.

A study on infants based on the impedance-pHmetry and cardiorespiratory monitoring reported a $30 \%$ association between short episodes of apnea and reflux (19).

Recurrent pneumonia and interstitial pneumonia can be complications of reflux, probably following the failure of the respiratory tract protection mechanisms to protect the lungs from the gastric aspirate (20).

Children with respiratory complications are generally considered the most susceptible to benefit from anti-reflux surgery when medical treatment fails, but additional studies are necessary to confirm this hypothesis (21).

\section{Neurobehavioural manifestations}

The neurobehavioural manifestations are represented by sleeping disorders, agitation and crying crises, arching and rigidity, hyperextension of the neck, generalized irritability, sometimes convulsions or well-proven pseudo-psychiatric behaviour.

Particularly, in the older child, the Sandifer syndrome manifests by head extension, torticollis, opisthotonus postures, sometimes with facial asymmetry. It is associated with hiatal herniation, and $50 \%$ of the cases also have esophagitis lesions.

\section{Nutritional consequences}

The nutritional consequences cause failure to thrive, "weight faltering", signs of chronic dehydration, even chronic ketosis and microcytic hypochromic anemia.

\section{PARACLINICAL ASPECTS}

Generally, the medical history told by the parents is sufficient to diagnose reflux, especially if the problems appears regularly and causes discomfort.

Usually, GERD is not investigated or treated in infants without regurgitations and showing only one of the following: inexplicable feeding difficulties (for instance, food refusal), unusual behaviour, growth difficulty, chronic cough, dysphonia, only one pneumonia episode (18).

The growth chart and feeding history are also of help, but occasionally additional tests are recommended.

As regards the GERD diagnosis, the AJT (The American Journal of Gastroenterology) Guides from 2013 recommend:
1. A presumptive GERD diagnosis can be set in typical cases with regurgitations. Empirical medical treatment with a proton-pump inhibitor (PPI) is recommended in this case.

2. The eso-gastro-duodenal barium swallow examination is not to be done to diagnose GERD.

3. Upper digestive endoscopy is not necessary in the presence of typical GERD symptoms. Endoscopy is recommended in the presence of alarming symptoms and for the screening of patients with high risk of complications. It is not indicated to repeat endoscopy in patients lacking Barret's esophagus or in the absence of over-added symptoms.

4. Biopsies from the distal esophagus are not recommended as a routine in diagnosing GERD.

5. Esophageal manometry is recommended for postoperative evaluation, but it is not to be used in diagnosing GERD.

6. Outpatient monitoring of esophageal reflux is indicated before considering endoscopy or surgical treatment in patients with non-erosive reflux disease, as part of the evaluation of patients' refractory to the PPI therapy and when the GERD diagnosis is uncertain. The outpatient monitoring of the esophageal reflux is the only test that can evaluate the association of reflux with other symptoms.

7. The screening for the Helicobacter pylori $(H$. Pylori) infection is not recommended in GERD. The eradication of the Helicobacter pylori (H. pylori) infection is not a routine necessity as part of the anti-reflux therapy (22).

Outpatient monitoring of gastro-esophageal reflux (pH-metry or impedance-pH-metry) is a test allowing the tracking of abnormal esophageal exposure to acid, the frequency of reflux and the symptoms associated with the reflux episodes.

$\mathrm{PH}$-metry is the investigation technique of the highest sensitivity (77-100\%) and specificity (85$100 \%$ ) in detecting and quantifying acid GER. The impedance-pH-metry increases the sensitivity for the detection of reflux to almost $90 \%$ (23).

Esophageal impedance is a technique used to detect the movement of (acid and alkali) fluids, solids and gases in the esophageal lumen. This can be used to measure the volume, the speed and physical length of the esophageal bolus. Impedance-pH-metry has the same indications as $\mathrm{pH}$-metry, being useful especially in evaluating intermittent symptomatology such as cough, dysphagia or apnea. Thus, for the past few years it has been used to in- 
vestigate how GER and GERD correlate with apnea, cough and neurobehavioural disorders.

$\mathrm{pH}$-metry and impedance-pH-metry are recommended in infants suspected of recurrent aspiration pneumonia, inexplicable apnea, upper airways infections, dental erosions associated with neurodisability, frequent otitis media, possible need to perform a fundoplication (18).

Upper digestive endoscopy allows the direct examination of the esophageal mucous membrane.

\section{REFERENCES}

1. Jadcherla S.R., Shaker R. Esophageal and upper esophageal sphincter motor function in abies. Am J Med. $2001 \mathrm{Dec}$ 3; 111 Suppl 8A:64S-68S

2. Dusick A.M. Medical outcomes in preterm infants. Semin Perinatol. 1997 Jun; 21(3):164-77

3. Orenstein S.R., Shalaby T.M., Cohn J.F. Reflux symptoms in 100 normal infants: diagnostic validity of the infant gastroesophageal reflux questionnaire. Clin Pediatr (Phila). 1996 Dec; 35(12):607-14

4. Vandenplas Y., Belli D., Benhamou P.H. et al. Current concepts and issues in the management of regurgitation of infants: a reappraisal. Management guidelines from a working party. Acta Paediatr. 1996 May; 85(5):531-4

5. Kelmanson I.A. Repetitive regurgitation and behavioural features in 2-4-month-old infants. Padiatr. Grenzgeb. 2000b; 39(5-6):465-476

6. Tobin J.M., McCloud P., Cameron D.J. Posture and gastro-oesophageal reflux: a case for left lateral positioning. Arch Dis Child. 1997 Mar; 76(3):254-8

7. Badriul H., Vandenplas Y. Gastro-oesophageal reflux in infancy. J Gastroenterol Hepatol. 1999 Jan; 14(1):13-9

8. Jiang J.C., Ewigman B., Danis P. Clinical inquiries. Should we change formula for a formula-fed infant with persistent spitting up, but with adequate weight gain? J Fam Pract. 2001 Jul; 50(7):576-7

9. Orenstein S.R., Shalaby T.M., Cohn J.F. Reflux symptoms in 100 normal infants: diagnostic validity of the infant gastroesophageal reflux questionnaire. Clin Pediatr (Phila). 1996 Dec; 35(12):607-14

10. Sondheimer J.M. The meaning of "S". J Pediatr Gastroenterol Nutr. 2003 Feb; 36(2):170-1

11. Herbst A. [Prevention of perinatal asphyxia. Can more be done by fetal monitoring?]. Lakartidningen. 2000 Aug 9; 97(32-33):3484-8

12. Reust C.E., Blake R.L. Jr. Diagnostic workup before diagnosing colic. Arch Fam Med. 2000 Mar; 9(3):282-3

13. Jung A. Gastroesophageal reflux in infants and children. American Family Physician. 2001; 64(11):1853-7

14. Orenstein S.R., Hassall E., Furmaga-Jablonska W., et al. Multicenter, double-blind, randomized, placebo-controlled trial assessing efficacy \& safety of proton pump inhibitor lansoprazole in infants with symptoms of gastroesophageal reflux disease. J Pediatr 2009; 154:514-20

15. Nielsen R.G., Bindslev-Jensen C., Kruse-Andersen S., et al. Severe gastroesophageal reflux disease and cow milk hypersensitivity in infants and children: disease association and evaluation of a new challenge procedure. J Pediatr Gastroenterol Nutr 2004; 39:383-91

16. lacono G., Carroccio A., Cavataio F., et al. Gastroesophageal reflux and cow's milk allergy in infants: a prospective study. J Allergy Clin Immunol 1996; 97:822-7

17. Malcolm A., Thumshirn M.B., Camilleri M., Williams D.E. Rumination syndrome. Mayo Clin Proc. 1997 Jul; 72(7):646-52

18. NICE guideline. Gastro-oesophageal reflux disease in children and young people: diagnosis and management. Published: 14 January 2015. Last accesed: 07.11.2015 at http://www.nice.org.uk/guidance/ ng1
The macroscopic lesions associated with GERD are represented by esophagitis, erosions, exudate, ulcerations, strictures, hiatal herniation, areas of esophageal metaplasia and sometimes polyps. Sensitivity, specificity and the predictive positive value vary from $29 \%$ to $86 \%$, from $21 \%$ to $83 \%$ and from $80 \%$ to $82 \%$ respectively, if we are to compare the pH-metry results $(24,25)$.

19. Wenzl T.G., Schenke S., Peschgens T., et al. Association of apnea and nonacid gastroesophageal reflux in infants: investigations with the intraluminal impedance technique. Pediatr Pulmonol 2001; 31:144-9

20. Boesch R.P., Daines C., Willging J.P., et al. Advances in the diagnosis and management of chronic pulmonary aspiration in children. Eur Respir J 2006; 28:847-61

21. Vandenplas Y., Rudolph C.D., Di Lorenzo C. et al. Pediatric gastroesophageal reflux clinical practice guidelines: joint recommendations of the North American Society for Pediatric Gastroenterology, Hepatology and Nutrition (NASPGHAN) and the European Society for Pediatric Gastroenterology, Hepatology and Nutrition (ESPGHAN). J Pediatr Gastroenterol Nutr 2009; 49:498-547

22. Philip O. Katz, Lauren B. Gerson and Marcelo F. Vela, MD. Guidelines for the Diagnosis and Management of Gastroesophageal Reflux Disease. Am J Gastroenterol 2013; 108:308-328

23. Sifrim D., Castell D., Dent J. et al. Gastro-oesophageal reflux monitoring: review and consensus report on detection and definitions of acid, non-acid, and gas reflux. Gut 2004; 53:1024-31

24. Chen M.Y., Ott D.J., Sinclair J.W., et al. Gastroesophageal reflux disease: correlation of esophageal $\mathrm{pH}$ testing and radiographic findings. Radiology 1992; 185:483-6

25. Aksglaede K., Pedersen J.B., Lange A., et al. Gastro-esophageal reflux demonstrated by radiography in infants less than 1 year of age. Comparison with pH monitoring. Acta Radiol 2003; 44:136-8

26. Martin A.J., Pratt N., Kennedy J.D., et al. Natural history and familial relationships of infant spilling to 9 years of age. Pediatrics 2002; 109:1061-7

27. Osatakul S., Sriplung H., Puetpaiboon A., et al. Prevalence and natural course of gastroesophageal reflux symptoms: a 1-year cohort study in Thai infants. J Pediatr Gastroenterol Nutr 2002; 34:63-7

28. Barak M., Lahav S., Mimouni F.B., et al. The prevalence of regurgitations in the first 2 days of life in human milk- and formula-fed term infants. Breastfeed Med 2006; 1:168-71

29. Khoshoo V., Ross G., Brown S., et al. Smaller volume, thickened formulas in the management of gastroesophageal reflux in thriving infants. J Pediatr Gastroenterol Nutr 2000; 31:554-6

30. Georgescu A. Compendiu de pediatrie, editia a II-a. Ed. Bic All, Bucureşti, 2005; 389-391

31. Rudolph C.D., Mazur L.J., Liptak G.S. et al. Guidelines for evaluation and treatment of gastroesophageal reflux in infants and children: recommendations of the North American Society for Pediatric Gastroenterology and Nutrition. J Pediatr Gastroenterol Nutr. 2001; 32 Suppl 2:S1-31

32. Jiang J.C., Ewigman B., Danis P. Clinical inquiries. Should we change formula for a formula-fed infant with persistent spitting up, but with adequate weight gain? J Fam Pract. 2001 Jul; 50(7):576-7

33. Oyen N., Markestad T., Skaerven R., Irgens L.M., HelwegLarsen K., Alm B., et al. Combined effects of sleeping position and prenatal risk factors in sudden infant death syndrome: the Nordic Epidemiological SIDS Study. Pediatrics 1997; 100: 613-21 
34. Orenstein S.R., Whitington P.F. Positioning for prevention of infant gastroesophageal reflux, The Journal of Pediatrics, 1983, 103, 4:534-537

35. Vandenplas Y., Belli D., Benhamou P. et al. A critical appraisal of current management practicies for infant regurgitation - recommendations of a working party. Eur J Pediatr 1997; 156: 343-357

36. Bhat R.Y., Rafferty G.F., Hannam S., Greenough A. Acid gastroesophageal reflux in convalescent preterm infants: effect of posture and relationship to apnea. Pediatr Res 2007; 62: 620-3

37. Hassall E. Decisions in diagnosing and managing chronic gastroesophageal reflux disease in children. J Pediatr 2005; 146:S3-S12

38. Walker W.A. et al. Pediatric Gastrointestinal Disease, editia a IV-a Ed. BC Decker Inc, Hamilton, 2004; 384-399

39. Castot A., Bidault I., Dahan R et al. Bilan des effets inattendus et toxiques de l'oméprazole $\left(\right.$ Mopral $\left.^{\circledR}\right)$ rapportés aux centres régionaux de pharmacovigilance, au cours des 22 premiers mois de commercialisation. Thérapie, 1993, 48:469-474

40. Sutphen J.L., Dillard V.L. Effect of ranitidine on twenty-four-hour gastric acidity in infants. J Pediatr 1989; 114:472-4

41. Paul K., Redman C.M., Chen M. Effectiveness and safety of nizatidine, $75 \mathrm{mg}$, for the relief of episodic heartburn. Aliment Pharmacol Ther 2001; 15: 1571-1577

42. Spechler S.J., Goyal R.K. The columnar-lined esophagus, intestinal metaplasia, and Norman Barrett. Gastroenterology 1996; 110:614-621.
43. Lagergren J., Bergstrom R., Lindgren A., Nyren O. Symptomatic gastroesophageal reflux as a risk factor for esophageal adenocarcinoma. N Engl J Med 1999; 340:825-831

44. Rakita S., Villadolid D., Thomas A., Bloomston M., Albrink M., Goldin S., Rosemurgy A. Laparoscopic Nissen fundoplication offers high patient satisfaction with relief of extraesophageal symptoms of gastroesophageal reflux disease. Am Surg 2006; 72:207-212

45. Meyer T.K., Olsen E., Merati A. Contemporary diagnostic and management techniques for extraesophageal reflux disease. Curr Opin Otolaryngol Head Neck Surg 2004; 12:519-524

46. Lindstrom D.R., Wallace J., Loehrl T.A., Merati A.L., Toohill R.J. Nissen fundoplication surgery for extraesophageal manifestations of gastroesophageal reflux (EER). Laryngoscope 2002; 112:1762-1765

47. Smith C.D., Othersen H.B. Jr., Gogan N.J., et al. Nissen fundoplication in children with profound neurologic disability. High risks and unmet goals. Ann Surg 1992; 215:654-8

48. Spitz L., Roth K., Kiely E.M., et al. Operation for gastro-oesophageal reflux associated with severe mental retardation. Arch Dis Child 1993; 68:347-51

49. Diaz D.M., Gibbons T.E., Heiss K., et al. Antireflux surgery outcomes in pediatric gastroesophageal reflux disease. Am J Gastroenterol 2005; 100:1844-52 